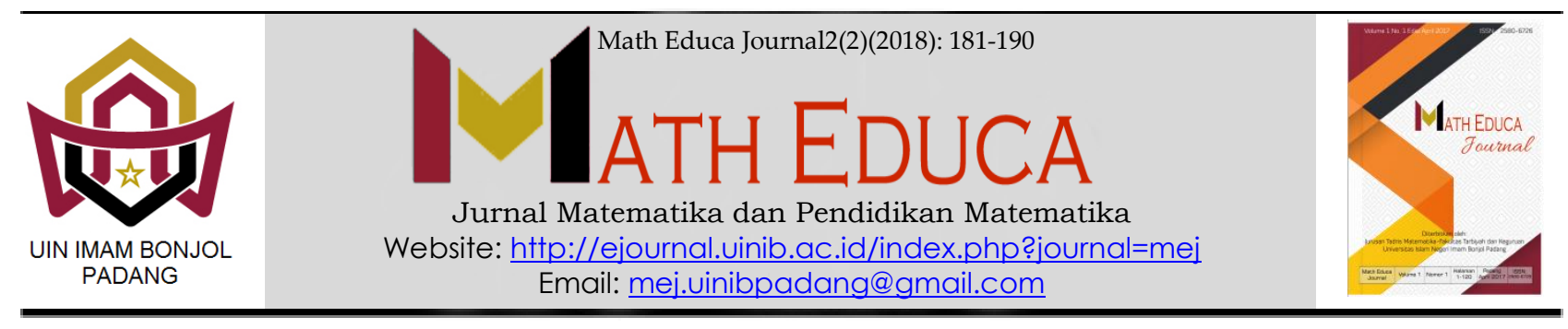

\title{
ETHNOMATHEMATICS PADA ORNAMEN RUMAH GADANG MINANGKABAU
}

\author{
Rozi Fitriza
}

Tadris Matematika, Fakultas Tarbiyah dan Keguruan, UIN Imam Bonjol Padang, Indonesia e-mail: rozifitriza.mtk@gmail.com; rozifitriza@uinib.ac.id

\begin{abstract}
Abstrak
Konsep matematika pada benda-benda budaya adalah salah satu objek kajian dalam studi ethnomathematics. Penelitian ini bertujuan untuk mengungkap konsep-konsep matematika pada ornamen yang terdapat pada rumah gadang dan pengembangan ornamennya. Penelitian kualitatif ini menggunakan teknik observasi partisipatori dan dokumentasi untuk memperoleh data. Hasil penelitian menunjukkan terdapat konsep-konsep geometri pada ornamen dan pengembangan ornamen rumah gadang. Konsep geometri yang terlihat pada ornamen diantaranya adalah penggunaan bangun-bangun datar seperti persegi, persegi panjang, belah ketupat, lingkaran, elips dan bangun datar segi-n. Bangun datar tersebut juga disusun menggunakan pola-pola tertentu. Pengembangan bentuk ornamen dilakukan dengan menggunakan prinsip kesebangunan, pengubinan, pola-pola simetri dan transformasi geometri (translasi, refleksi, rotasi, dan dilatasi). Hasil penelitian ini dapat dijadikan referensi bagi guru dalam pembelajaran matematika dan penelitian ethnomathematics pada benda-benda budaya.

Kata kunci: Ethnomathematics, ornamen rumah gadang.

\section{Abstract}

The mathematical concept on cultural objects is one of the objects of study in the study of ethnomathematics. This study aims to uncover mathematical concepts in the ornaments found in the rumah gadang and the development of ornaments. This qualitative research uses participatory observation techniques and documentation to obtain data. The results showed that there were geometrical concepts in the ornaments and the development of the rumah gadang ornaments. The concepts of geometry seen in ornaments include the use of two-dimensional such as square, rectangular, rhombic, circle, ellipse and polygons. Two-dimensional shape are also arranged using certain patterns. The development of ornament forms is carried out using the principles of congruence, tessellation, symmetry patterns and geometric transformations (translation, reflection, rotation, and dilation). The results of this study can be used as a reference for teachers in mathematics learning and ethnomathematics research on cultural objects.
\end{abstract}

Keywords: ethnomathematics, ornaments of rumah gadang. 


\section{PENDAHULUAN}

Etnomatematika dapat dipandang sebagai sebuah studi yang mengkaji bagaimana orang-orang dari suatu kelompok budaya memahami, mengartikulasi, dan menggunakan konsep-konsep serta praktek-praktek yang berasal dari budaya mereka, dimana dipandang oleh peneliti sebagai sesuatu yang bersifat matematis (Barton, 1996). Menurut D’Ambrosio (2001) ethnomathematics, menggambarkan hubungan antar matematika dan budaya, terdiri dari kata ethno dan mathematics. Ethno adalah semua unsur yang membangun identitas budaya dari sebuah grup, seperti: bahasa, kode, nilai, jargon, kepercayaan, makanan dan pakaian, kebiasaan, dan ciri fisik. Sedangkan matematika meliputi aritmetika, pengklasifikasian, pengurutan, penyimpulan dan pemodelan.

Ethnomathematics adalah sebuah kajian matematika pada wujud kebudayaan (ide, aktivitas, atau benda budaya) yang sudah menjadi kekhasan/ciri dari suatu kelompok masyarakat. Kajian dilakukan oleh seseorang yang memiliki pengetahuan/keahlian dalam bidang matematika (Fitriza, R., 2018). Beberapa pandangan tentang ethnomathematics di atas membantah pandangan yang selama ini berkembang, tentang matematika tidak ada kaitannya dengan budaya (math is cultural-free).

Sebagai sebuah studi ethnomathematics menjadikan ide-ide/konsep dan aktivitas suatu kelompok budaya sebagai objek kajiannya. Sehingga sangat memungkinkan untuk melakukan eksplorasi konsep matematika terhadap berbagai khasanah budaya Indonesia.

Sumatera Barat dikenal dengan "Minangkabau" daerah yang terletak di bagian pantai barat Sumatera memiliki berbagai wujud kebudayaan yang khas. Mulai dari berbagai aktivitas budaya dari suku-suku yang ada sampai benda budaya/artefak dari zaman purba. Salah satu wujud kebudayaan yang menonjol dari suku Minangkabau adalah rumah gadang.

Rumah tradisional Minangkabau disebut rumah gadang (rumah besar). Istilah rumah gadang bukan hanya karena fisiknya yang besar melainkan karena fungsinya yang "luas", selain tempat kediaman suatu keluarga, juga melambangkan kehadiran suatu kaum dalam satu nagari serta tempat kegiatan sosial masyarakat suatu kaum (Navis, 2015).

Konstruksi bangunan rumah gadang unik dan menarik. Ciri khas rumah gadang yang sangat menonjol adalah bentuk atapnya yang melengkung dan menjulang pada kedua ujungnya. Jika dilihat dari depan menyerupai tanduk kerbau, bagian ini disebut dengan gonjong. Bentuknya besar ke atas hampir menyerupai sebuah perahu. Hal ini dikarenakan tiang-tiang ditegakkan dengan kemiringan $91^{\circ}$ 94. Besar rumah gadang ditentukan oleh banyak ruang dan lanjar (Soeroto, 2005; Syamsidar, 1991).

Kemegahan rumah gadang dilengkapi dengan berbagai bentuk ornamen-ornamen yang terdapat padanya. Ornamen menurut John Firtz Maurice Miles adalah sesuatu yang 
ditambahkan secara estetis pada bentuk atau fungsi sebuah objek. Ornamen dapat berupa lukisan atau ukiran dekoratif. Ragam hias/ornamen tidak ada hubungan dengan konstruksi sebuah bangunan (A.M.Y Dt. Garang, 1983, hlm. 46). Ornamen dapat juga berupa hiasan bergaya geometrik atau yang lainnya.

Penelitian ethnomathematics yang menjadikan ornamen sebagai objek kajiannya telah dilakukan oleh beberapa peneliti diantaranya Massarwe, Verner, Bshouty (2015) menggunakan tugas ethnomathematics merancang ornamen di kelas geometri di kelas sekolah menengah atas di Israel; Haryanto, Nusantara, Subanji \& Abadyo. (2016) meneliti tentang konsep matematika pada simpul tonggak pada rumah arfak Papua. Fauziah dan Niniwati (2017) mengidentifikasi jenis-jenis ukiran yang terdapat pada rumah gadang di daerah Solok Selatan, Sumatera Barat kemudian melihat sifat-sifat simetrinya. Hal yang sama juga dilakukan oleh Khaira (2017), meneliti ide matematis pada ukiran rumah adat Minangkabau, kemudian hasil investigasi dijadikan bahan ajar untuk pembelajaran simetri di Sekolah Dasar (SD).

Berdasarkan paparan di atas maka sangat menarik untuk mengungkap konsep matematika pada ornamen-ornamen yang terdapat pada rumah gadang. Ornamen yang diteliti tidak hanya ukiran, tetapi meliputi ornamen/ragam hias bagian dalam (interior) dan luar (eksterior) pada rumah gadang.

\section{METODE PENELITIAN}

Bagian metode penelitian membahas tentang: desain penelitian, tempat penelitian, teknik pengumpulan data, dan teknik analisis data. Berikut ini uraian masing-masing bagian tersebut.

\section{Desain Penelitian}

Penelitian ini adalah bagian dari penelitian tentang studi ethnomathematics pada arsitektur tradisional rumah gadang Sumatera Barat. Penelitian ini menggunakan pendekatan penelitian kualitatif. Penelitian kualitatif menurut Creswell (2009) adalah suatu proses penelitian yang dilakukan dalam latar yang alamiah untuk memahami masalah sosial, informasi disajikan secara jelas dengan penggambaran secara menyeluruh dan kompleks dengan menggunakan kata-kata.

\section{Tempat Penelitian}

Penelitian ini dilaksanakan di 3 Luhak yang dikenal dengan 'Luhak Nan Tigo', yang meliputi: Luhak Tanah Datar, berpusat di Batusangkar; Luhak Agam, berpusat di Bukittinggi dan Luhak Limapuluh Kota, berpusat di Payakumbuh.

Rumah gadang yang memiliki ciri arsitektur tradisional yang berumur minimal 100 tahun adalah objek dalam penelitian ini. Penelitian dimulai dari rumah-rumah gadang di desa Pariangan Luhak Tanah Datar yang diyakini sebagai asal nenek moyang suku Minangkabau. Penelitian dilanjutkan ke rumah gadang Kampai 
nan Panjang yang telah berumur lebih dari 350 tahun, di desa Balimbing Luhak Tanah Datar.

Penelitian di Luhak Agam dimulai dari rumah gadang di nagari Sungai Janiah diteruskan ke nagari Tilatang Kamang dan nagari Panyalaian. Penelitian di daerah Luhak 50 Kota dilakukan terhadap rumah-rumah gadang di Kenagarian Koto nan Gadang, Koto nan Ampek dan daerah Balubus sekitarnya.

\section{Teknik Pengumpulan Data}

Pada penelitian kualitatif pengumpulan data dilakukan dalam kondisi alamiah (natural setting). Teknik pengumpulan data lebih banyak menggunakan observasi parsipatori dan dokumentasi.

Observasi dilakukan untuk mengamati ornamen rumah gadang untuk selanjutnya diungkap konsep matematika yang terdapat pada ornamen tersebut. Lembar observasi dirancang, didasarkan pada aktivitas matematika yang dikemukakan oleh A.J. Bishop, yang terdiri atas: counting, measuring, locating, designing dan playing. Observasi dilengkapi dengan pengambilan foto.

\section{Teknik Analisis Data}

Pada penelitian kualitatif peneliti terlebih dahulu melakukan analisis induktif. Menurut Lincoln dan Guba (1992) dalam analisis induktif ada dua kegiatan yang dilakukan; pertama adalah pengelompokan (unitizing), yaitu mengidentifikasi unit informasi yang terpisah dari teks dengan disertai pemberian kode; kedua adalah kategorisasi (categorizing), yaitu menyusun dan mengorganisasikan data berdasarkan persamaan makna. Proses ini memerlukan revisi, modifikasi, dan perubahan yang berlangsung terus menerus sampai informasi baru dapat ditempatkan dalam kategori yang tepat dan pemasukan informasi tambahan menjadi suatu kategori dan tidak merupakan pemberian informasi baru.

\section{HASIL PENELITIAN DAN PEMBAHASAN}

Pengamatan dimulai dari ornamen interior rumah. Tonggak adalah bagian utama dalam pembangunan rumah gadang. Ornamen terlihat pada tonggak, baik pada bagian bawah atau bagian atas tonggak. Hiasan/ornamen pada tonggak seperti terlihat pada gambar 1. Pada bagian atas tonggak terdapat ukiran helaian daun. Pada ornamen gambar 1 (a) terlihat prinsip simetri, dimana sumbu simetrinya adalah tulang daun tersebut. Sedangkan pada gambar 1(b). terlihat bangun segi-8 yang mengelilingi tonggak.

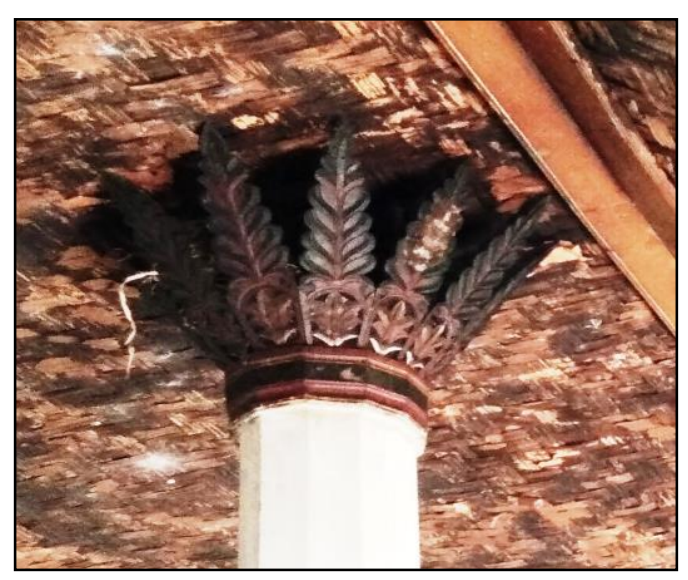

(a) 


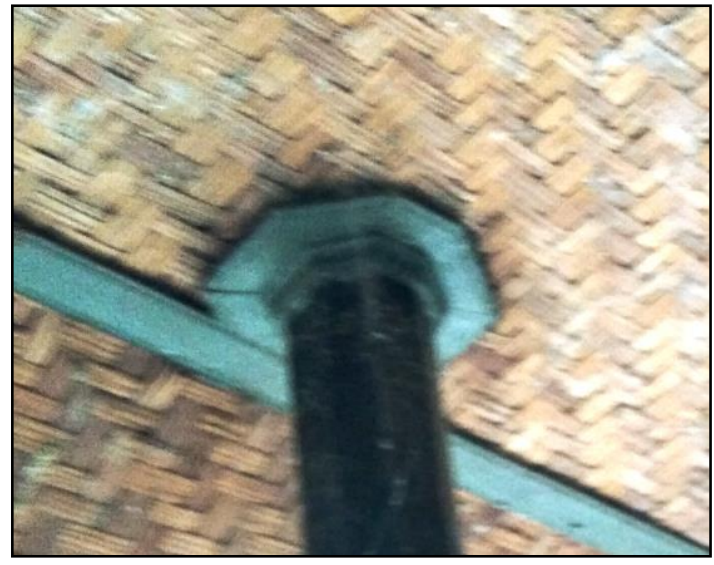

(b)

\section{Gambar 1. Hiasan Pada Bagian Atas Tonggak}

Selanjutnya terdapat dekorasi pintu bilik berupa bangun-bangun datar, seperti: persegi panjang, lingkaran dan elips (Gambar 2(a)), sedangkan daun pintu bilik rumah gadang Kampai nan Panjang yang telah berusia lebih dari 350 tahun berbentuk elips dengan hiasan belah ketupat-belah ketupat yang sebangun (gambar 2(b)). Daun pintu berbentuk elips dengan ukuran $60 \mathrm{~cm} \times 48 \mathrm{~cm}$, dengan sumbu panjang $2 \mathrm{a}=60 \mathrm{~cm}$ dan sumbu pendek $=48 \mathrm{~cm}$. Sehingga dapat diperoleh luas kayu untuk daun pintu berbentuk elips adalah $\pi a b=$ $\pi \times 30 \mathrm{~cm} \times 24 \mathrm{~cm}=720 \pi \mathrm{cm}^{2} \cong 2260,8 \mathrm{~cm}^{2}$.

Ornamen berbentuk bangun-bangun datar juga terdapat pada pintu bilik. Prinsip dilatasi bangun berlaku pada buhul pintu yang berbentuk belah ketupat yang sebangun (gambar 2(b). Dilatasi dengan pusat $\mathrm{O}$ dan faktor skala $k$, ditulis $D_{0, k}$ adalah pemetaan dimana: 1) jika $\mathrm{P}$ adalah titik yang berbeda dengan $\mathrm{O}$, maka $\mathrm{P}^{\prime}$ membentuk $\overrightarrow{O P}$ dan $O P^{\prime}=k$ $\cdot O P, 2)$ jika $\mathrm{P}$ sama dengan titik $\mathrm{O}$, maka titik $\mathrm{P}^{\prime}$ adalah $\mathrm{P}$

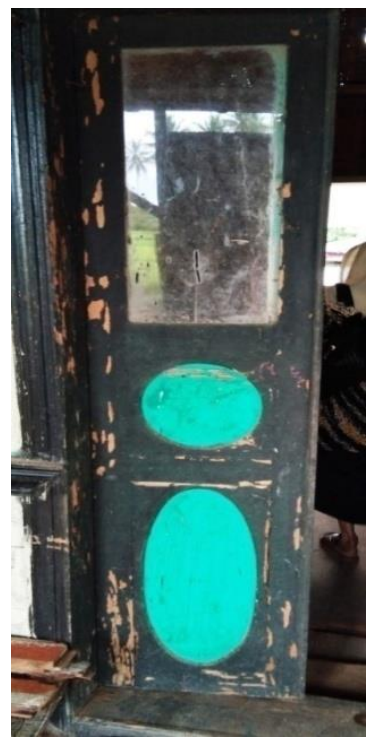

(a)

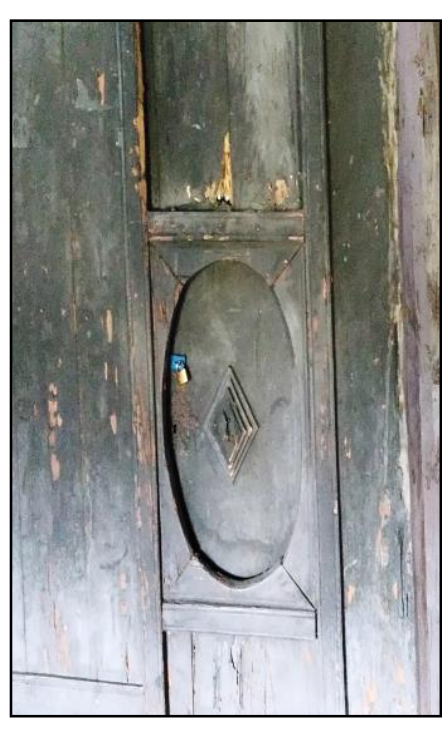

(b)

\section{Gambar 2. Pintu Bilik}

Ornamen eksterior seperti terdapat pada dinding depan rumah gadang juga bervariasi. Pada gambar 3(a) bagian bawahnya terdapat belah ketupat yang disusun pada masing-masing bagiannya sebanyak 3 buah. Di atas nya terdapat susunan bangun datar dengan pola 2 persegi panjang dan 1 persegi. Pada gambar 3(b) terlihat keserasian antara bentuk jendela dan kolong rumah, dimana sama-sama berbentuk setengah lingkaran. Dinding depan terbuat dari papan yang berbentuk persegi panjang yang disusun secara vertikal.

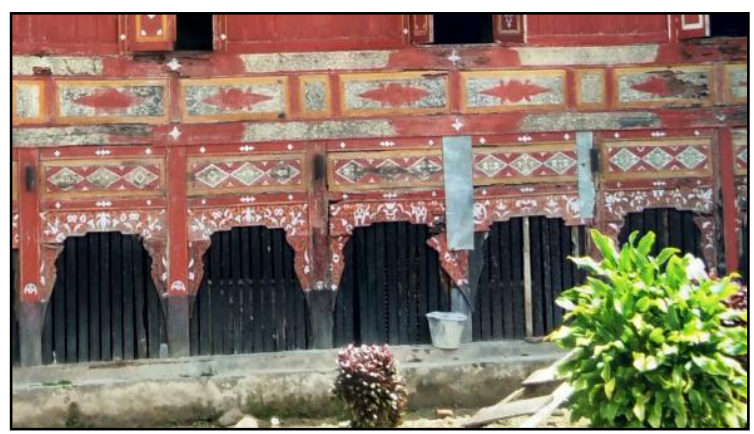

(a) 


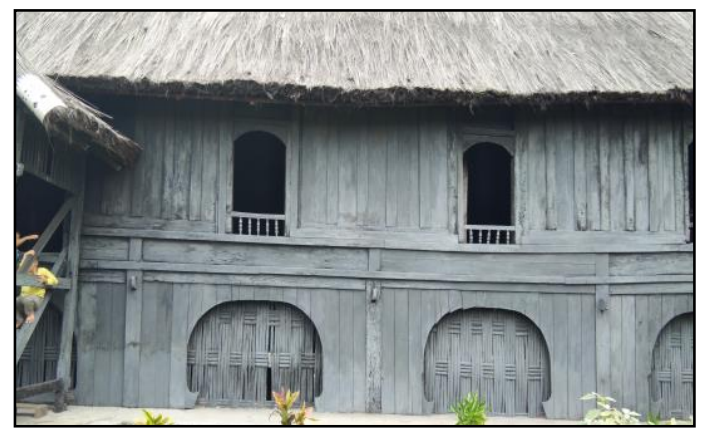

(b)

\section{Gambar 3. Ornamen Dinding Depan}

Ornamen yang paling menonjol pada sebuah rumah gadang adalah ukiran. Motif ukiran Minangkabau pada umumnya bersumber pada falsafah "alam takambang jadi guru". Bentuk-bentuk alam yang dijadikan motif ukiran tidak diungkapkan secara naturalis atau realistik, tetapi bentuk tersebut distilasi (merubah bentuk tanpa meninggalkan bentuk aslinya) sedemikian rupa sehingga menjadi bentuk yang dekoratif. Hal ini dikarenakan seni ukir naturalis tidak dipakai lagi di Minangkabau sejak masuknya Islam. Motif ukiran berasal dari tumbuhan, binatang, benda, manusia atau kondisi yang terjadi di masyarakat. Menurut Ibenzani Usman, motif ukiran pada rumah gadang ditempatkan pada tiga bagian: motif pengisi bidang besar, bidang kecil dan motif bidang besar yang lepas dan bebas fungsi (Hasni, S.1999, hlm., 11).

Berikut beberapa ukiran pada rumah gadang dan konsep matematika yang terdapat padanya. Umumnya pembuatan ukiran rumah gadang oleh para pengukir tradisional menggunakan prinsip transformasi geometri. Transformasi pada bidang adalah pemetaan, yang memenuhi sifat: 1 ) setiap titik pada bidang pasti memiliki satu image (bayangan), 2) setiap titik pada bidang pasti memiliki satu pre-image. Transformasi yang tidak mengubah jarak dinamakan isometris. Jenis-jenis dari isometri diantaranya adalah translasi, refleksi, dan rotasi (Jurgensen, Brown \& King, 1983)

Ukiran siriah gadang (sirih besar) berikut, dikembangkan menggunakan konsep translasi/pergeseran. Translasi adalah transformasi yang memetakan dua titik P dan Q ke $\mathrm{P}^{\prime}$ dan $\mathrm{Q}^{\prime}$ sehingga $\mathrm{PP}$ ' = QQ' dan $\mathrm{PQ}=\mathrm{P}^{\prime} \mathrm{Q}^{\prime}$. Semua titik yang bersesuaian memiliki jarak dan arah yang sama.

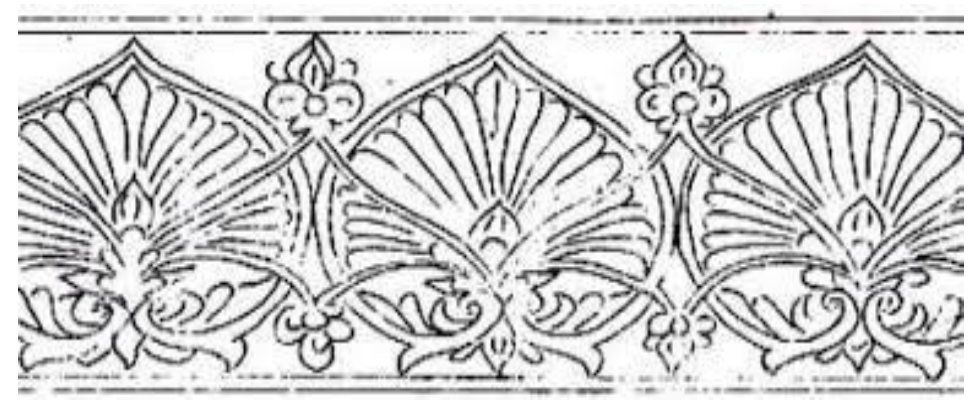

a. Ukiran siriah gadang

Ukiran bungo panco mato ari (bunga matahari), merupakan salah satu ukiran yang terletak pada bidang besar. Ukiran ini menggunakan konsep refleksi/pencerminan dalam pembuatan polanya. Refleksi memetakan titik $P$ ke titik $P^{\prime}$ dimana: 1) jika $P$ bukan merupakan cermin, maka cerminnya tegak lurus dan membagi dua ruas garis PP' (ditulis $M_{j}: P \rightarrow$ $P^{\prime}$ dengan $j$ adalah garis cermin), 2) jika $P$ merupakan cermin, maka $\mathrm{P}^{\prime}=\mathrm{P}$. 


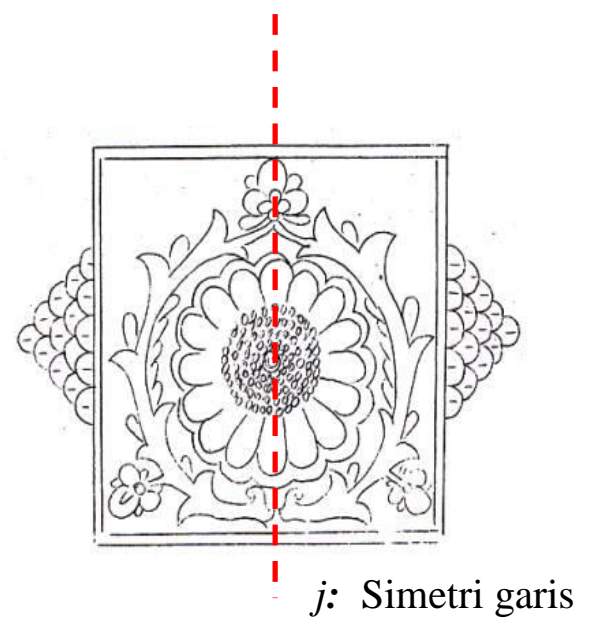

b. Bungo panco mato ari

Ukiran pucuak rabuang (pucuk rebung/bambu), yang dikembangkan motifnya melalui proses rotasi sebesar $180^{\circ}$. Rotasi dengan pusat rotasi $O$ sebesar $x^{\circ}\left(R_{0, \mathrm{x}}\right)<$ transformasi dimana: 1) jika titik $\mathrm{P}$ adalah titik yang berbeda dengan $\mathrm{O}$, maka OP' = OP dan $\left.\mathrm{POP}^{\prime}=x^{\circ}, 2\right)$ jika titk $\mathrm{P}$ sama dengan titk $\mathrm{O}$ maka $\mathrm{P}^{\prime}=\mathrm{O}$

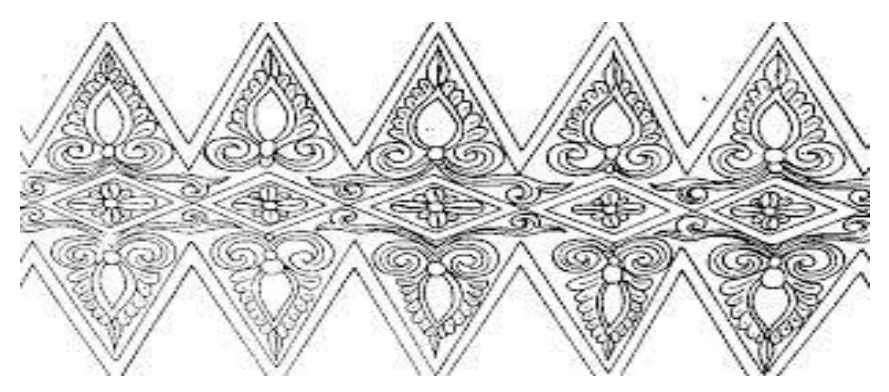

\section{c. Ukiran pucuak rabuag}

Motif ukiran di rumah gadang dapat juga terbentuk dari hasil transformasi objek nyata. Salah satu motif ukiran yang merupakan transformasi objek nyata adalah ukiran itiak pulang patang seperti terlihat pada gambar $4(d)$. Hasil stilasi dari keadaan nyata, keteraturan itik ketika pulang ke kandang di sore hari. Proses stilasi juga diterapkan pada ukiran bada mudiak (ikan kecil pipih) (A.M.Y Dt. Garang, 1983, hlm.. 114).

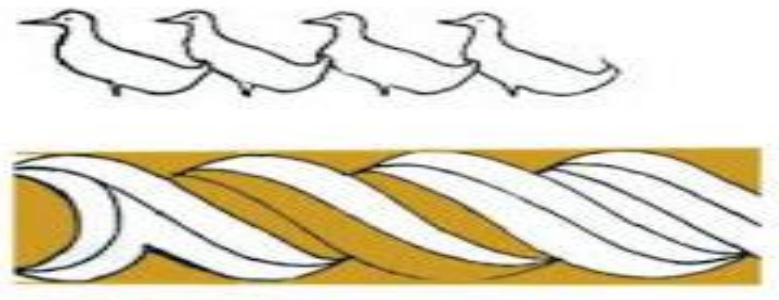

\section{d. Tranformasi dari bentuk itik ke motif itiak pulang patang \\ Gambar 4. Ukiran-ukiran pada Rumah Gadang}

Selain

penggunaan

konsep

transformasi dalam pengembangan motif ukiran, terlihat juga penggunaan konsep tessellation/pengubinan. Tessellation adalah pengulangan bentuk utuh yang kongruen pada bidang tanpa saling tumpang tindih satu sama lain. Tessellation ditemukan oleh Voronoi dan dikenal dengan Voronoi tessellation : "we are given a set of points $S$ in the plane, which are the Voronoi sites. Each site s has a Voronoi cell, also called a Dirichlet cell, $V(s)$ consisting of all points closer to $s$ than to any other site. The segments of the Voronoi diagram are all the points in the plane that are equidistant to the two nearest sites. The Voronoi nodes are the points equidistant to three (or more) sites". (Helsa\&Hartono, 2011)

Pola-pola simetri ditemukan juga pada beberapa ukiran rumah gadang seperti gambar berikut ini: 

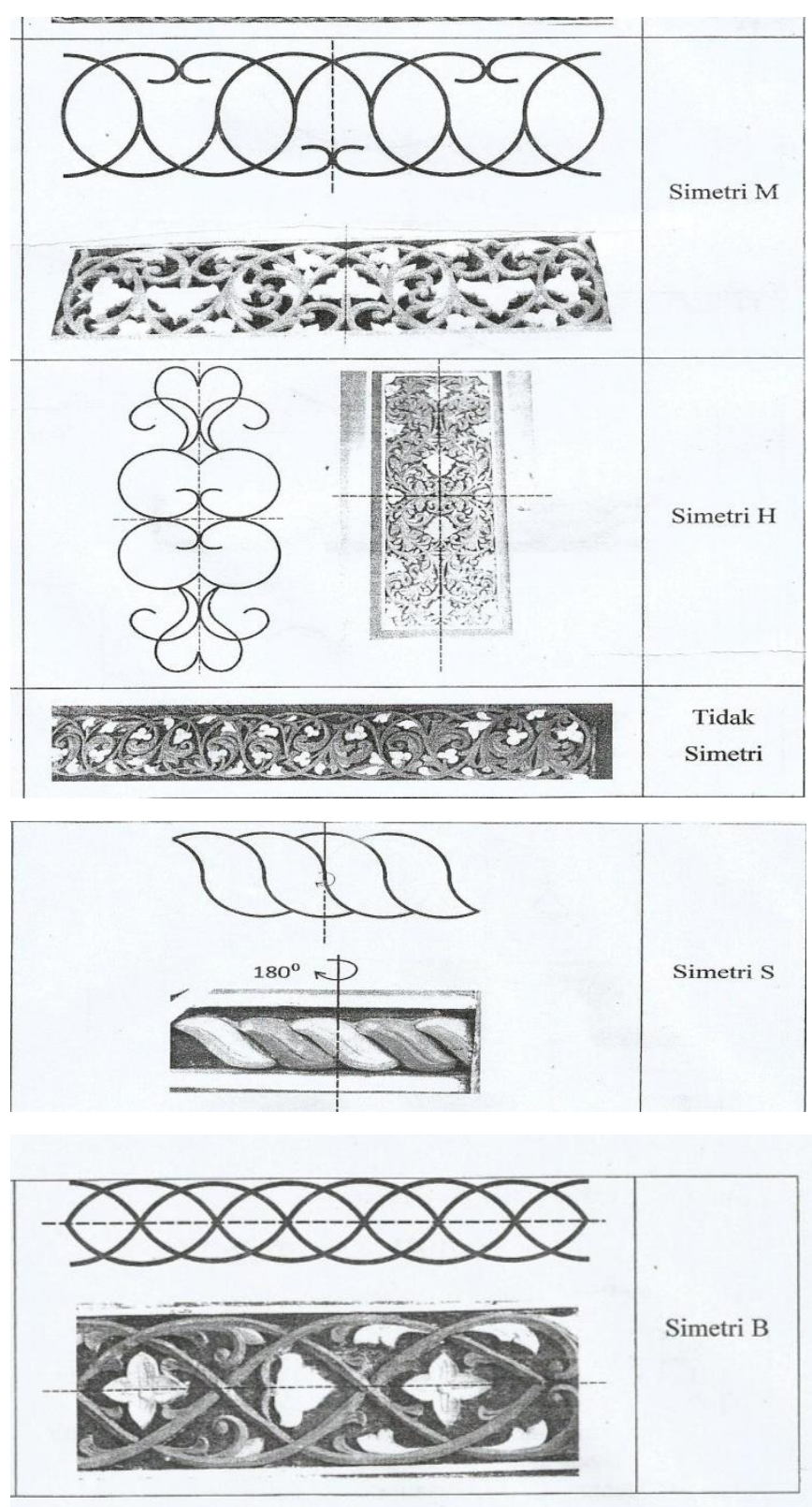

Gambar 5. Pola simetri pada ukiran rumah

gadang (Khaira, 2017)

Penamaan pola simetri $\mathrm{H}, \mathrm{M}, \mathrm{S}$ dan $\mathrm{B}$ didasarkan kepada penelitian Rosa dan Orey (2009) yang mengkaji pola-pola simetri pada selimut/potongan kain (quilts). Pola simetri $\mathrm{H}$, terdapat pada gambar yang memiliki garis vertikal sebagai simetri vertikal dan garis horizontal sebagi simetri horizontal. Simetri $M$ terdapat pada gambar yang hanya memiliki garis simetri vertikal, dimana motif pada sisi kiri hasil pencerminan dari motif sisi kanan. Simetri
S adanya ketika gambar diputar $180^{\circ}$ memiliki bentuk yang sama dengan gambar sebelum diputar. Simetri B yaitu gambar yang hanya memiliki garis simetri horizontal.

Pengembangan motif ukiran merupakan bagian dari aktivitas designing/perancangan. Hal utama pada aktivitas designing ini adalah mentransformasi bagian-bagian dari alam dan memodelkannya ke bentuk sesuatu, yang memungkinkan untuk menghilangkan bagian yang tidak penting, "designing concerns abstracting a shape from the natural environment" (A.J.Bishop, 1997: 39).

\section{SIMPULAN DAN SARAN}

Berdasarkan hasil penelitian dan pembahasan di atas, berikut simpulan penelitian dan saran bagi penelitian selanjutnya.

\section{Simpulan}

Dapat disimpulkan bahwa terdapat konsep-konsep geometri pada ornamen dan pengembangan ornamen rumah gadang. Konsep geometri yang terlihat pada ornamen diantaranya adalah penggunaan bangun-bangun datar seperti persegi, persegi panjang, belah ketupat, lingkaran, elips dan bangun datar segin. Bangun datar tersebut juga disusun menggunakan pola-pola tertentu. Pengembangan bentuk ornamen dilakukan dengan menggunakan prinsip kesebangunan, pengubinan, pola-pola simetri dan transformasi geometri (translasi, refleksi, rotasi, dan dilatasi) 
Saran

Hasil penelitian ethnomathematics pada ornamen rumah gadang dapat dijadikan referensi bagi guru-guru dalam merancang pembelajaran matematika yang menggunakan khasanah budaya bangsa. Peneliti ethnomathematics dapat mengungkap aspek matematika pada artefak-artefak budaya lainnya. Selain itu dapat juga dilakukan penelitian terhadap tukang kayu atau pengukir tradisional, untuk mengungkap pola berfikir matematika yang mereka gunakan dalam mendesain artefak/benda budaya.

\section{REFERENSI}

A.M.Y Dt. Garang, H. A. (1983). Pengetahuan Ragam Hias Minangkabau. Jakarta: Dirjen Pendidikan Dasar dan Menengah Depatemen Pendidikan dan Kebudayaan.

Barton, W. . (1996). Ethnomathematics : Exploring Cultural Diversity in Mathematics. University of Auckland.

Bishop, A. J. (1997). Mathematical Enculturation: A Cultural Perspective on mathematics Education (Third). The Netherlands: Kluwer Academic Publishers. https://doi.org/10.1007/978-94-0092657-8

Creswell, J, W. (2009). Research Design: Qualitative, Quantitative, and Mixed Methods Approaches. 3rd Edition. Los Angeles: SAGE Publications, Inc.

D'Ambrosio, U. (2001). What is ethnomathematics, and how can it help children in schools? Teaching Children Mathematics , 308.
Fauziah \& Niniwati. (2017). Ethno-mathematics Exploration on the Carvings of Rumah Gadang in South Solok Regency of West Sumatera. IJRDO-Journal of Educational Research , 134-148.

Fitriza, R., (2018). Studi Ethnomathematics Pada Arsitektur Tradisional Rumah Gadang Sumatera Barat dan Penerapannya Dalam Pembelajaran Matematika Di Sekolah. Bandung: Disertasi, Universitas Pendidikan Indonesia.

Haryanto, T. S, Nusantara, Subanji \& Abadyo. (2016). Ethnomathematics in Arfak (West Papua-Indonesia): Hidden Mathematics on knot of Rumah Kaki Seribu. Academic Journals , 420-425.

Hasni, S. (1999). Ukiran Tradisional Minangkabau. Padang: Depdikbud, Direktorat Jenderal Kebudayaan.

Helsa, Y., \& Hartono, Y. (2011). Designing Reflection and Symmetry Learning by Using Math Traditional Dance in Primary School. IndoMs - JME, 2(1), 79 - 94.

Jurgensen, R. B, Brown, R.G \& King, A. M. (1983). Geometry. Boston: Houghton Mifflin Company.

Khaira, K. (2017). Study of Ethnomathematics: Investigasi Ide Matematis Pada Ukiran Rumah Adat Tradisional Minangkabau. Bandung: Skipsi: UPI.

Massarwe, K.I. (2010). An Ethnomathematics Exercises in Analyzing and Constructing Ornaments in a Geometry Class. Journal of Mathematics and Culture, 5(1) .

Navis, A. (2015). Alama Takambang Jadi Guru: Adat dan Kebudayaan Minangkabau. Padang: PT Grafika Jaya Sunmbar.

Rosa, M. \& Orey, D.C. (2009). Symmetrical Freedom Quilts: The Ethnomathematics of Way of Communication, Liberation, 
190 Math Educa Journal Volume 2 No. 2 Edisi Oktober 2018, pp.181-190

and Art. Revista Latinoamericana de Etnomatematica, 2(2), 52-75

Soeroto, M. (2005). Pustaka Budaya dan Arsitektur: Minangkabau. Jakarta: Myrtle Publishing.
Syamsidar. (1991). Arsitektur Tradisional Daerah Sumatera Barat. Jakarta: Depdikbud, Direktorat Jendral Kebudayaan Direktorat sejarah dan Nilai Tradisional Proyek Inventarisasi dan Pembinaan Nilai-nilai Budaya. 